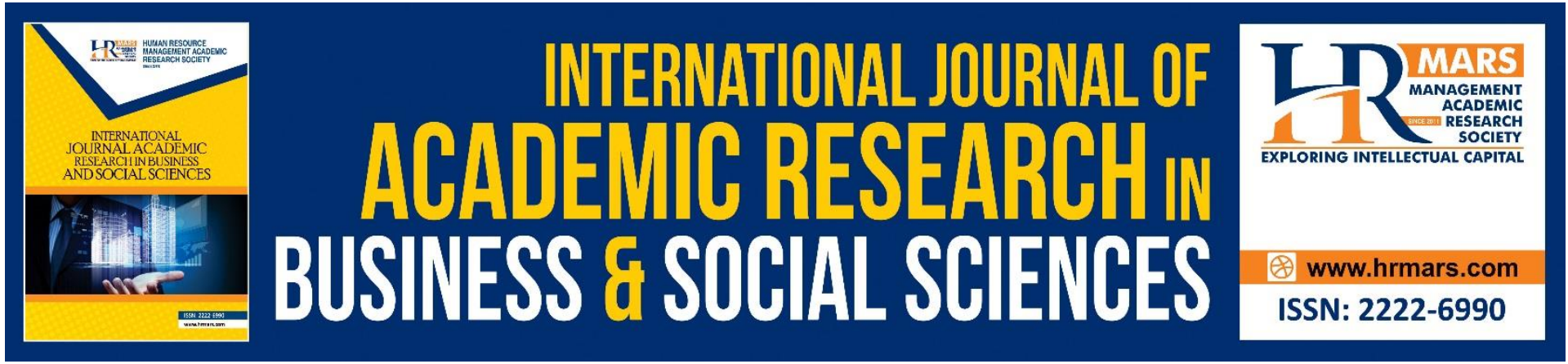

\title{
Resolving Learning Time and Space Constraints While Engaging in English language Learning-Acquisition among Open Distance Learners (ODL) Using Web-mobile Platforms; Edmodo and Telegram
}

Mohd Talha Mohd Idris, Supyan Hussin, Mohammad Talha Mohamed Idris, Supyan Hussin

To Link this Article: http://dx.doi.org/10.6007/IJARBSS/v11-i7/10590 DOI:10.6007/IJARBSS/v11-i7/10590

Received: 21 May 2021, Revised: 29 June 2021, Accepted: 15 July 2021

Published Online: 29 July 2021

In-Text Citation: (Idris et al., 2021)

To Cite this Article: Idris, M. T. M., Hussin, S., Idris, M. T. M., \& Hussin, S. (2021). Resolving Learning Time and Space Constraints While Engaging in English language Learning-Acquisition among Open Distance Learners (ODL) Using Web-mobile Platforms; Edmodo and Telegram. International Journal of Academic Research in Business and Social Sciences, 11(7), 1320-1331.

Copyright: @ 2021 The Author(s)

Published by Human Resource Management Academic Research Society (www.hrmars.com)

This article is published under the Creative Commons Attribution (CC BY 4.0) license. Anyone may reproduce, distribute, translate and create derivative works of this article (for both commercial and non-commercial purposes), subject to full attribution to the original publication and authors. The full terms of this license may be seen

at: http://creativecommons.org/licences/by/4.0/legalcode

Vol. 11, No. 7, 2021, Pg. 1320 - 1331

Full Terms \& Conditions of access and use can be found at http://hrmars.com/index.php/pages/detail/publication-ethics 


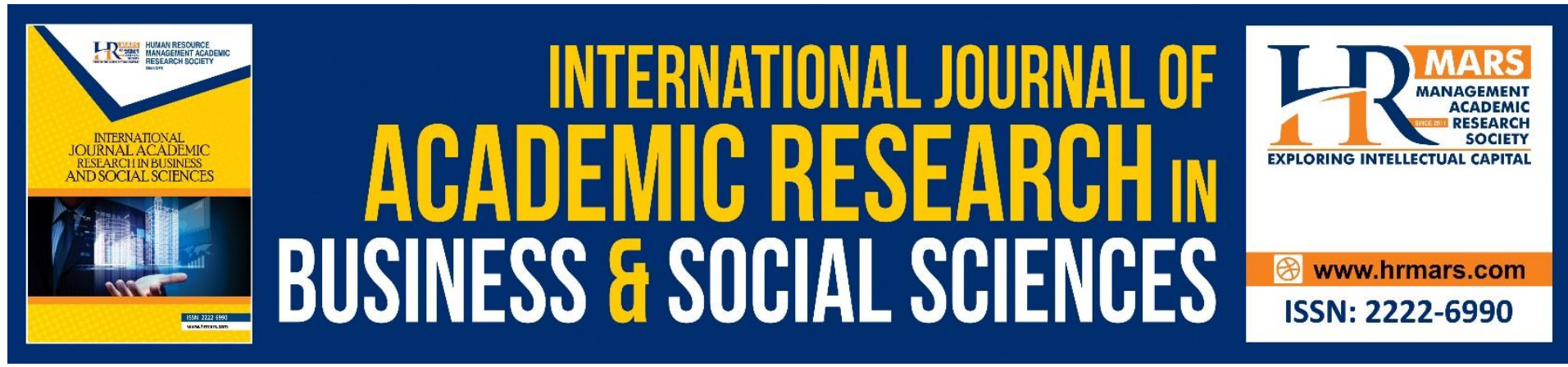

\title{
Resolving Learning Time and Space Constraints While Engaging in English language Learning- Acquisition among Open Distance Learners (ODL) Using Web-mobile Platforms; Edmodo and Telegram
}

\author{
Mohd Talha Mohd Idris, Supyan Hussin, Mohammad Talha \\ Mohamed Idris
}

Centre for Language Studies, Universiti Tun Hussein Onn Malaysia, 86400, Parit Raja, Johor, Malaysia

Email: talha@uthm.edu.my

Prof. Dr. Supyan Hussin

Centre for Research in Language and Linguistics, Universiti Kebangsaan Malaysia, 43600, Bangi, Selangor, Malaysia

Email: supyan@ukm.edu.my

\section{Abstract}

Distance learning refers to any form of remote education where learners and educators use different technologies as an alternative approach in teaching and learning process to be able to deliver and exchange information. The use of Web-Mobile Platforms (WMPs); Edmodo and Telegram in language learning-acquisition among the undergraduate ODLs (open distance learners) enabled learners and educators to stay connected. This study aims to generate insights and sharing through a questionnaire and in-depth interview questions procedure on Edmodo and Telegram to seek the emerging themes and identify learners' perceptions in terms of learning time and space constraints in both contexts. The WMPs were used as the platform to accommodate learners' language learning materials and online discussion forums thus functioned as the scaffolding to facilitate learners' language learning-acquisition process. The study employs purposively sampling involving eleven undergraduate ODLs from a Malaysian university. The findings are presented in a narrative manner to illustrate the emerging themes and the pedagogical implications pertaining to how the WMPs break barriers by providing learners access to learning resources beyond the classroom learning time and space constraints and opportunities to communicate with their peers suggesting practicality and convenient ways of engaging in language learningacquisition via the WMPs thus bridge physical space and time constraints between them.

Keywords: WMPs, Edmodo, Telegram, Scaffolding, ODLs, Language Learning-acquisition 


\section{Introduction}

Distance learning refers to any form of remote education where learners are not physically present for the lesson and is growing fast now with the internet accessibility as an alternative in teaching and learning process (What is Distance learning?, 2020). There is a rise in flexibility and affordable education options. Distance education is clearly different from normal face-to-face classroom situation in terms of a learner or teacher's physical presence. "Unlike the face to face discussion in the classroom that is limited by learning space and time, e-forums allows teachers and learners to interact with one another outside the four walls and specified time", (Hussin, 2006).

Technology skilled educators will continue to be integral part of learners' life while technology bridge the physical spaces and time constraints between teachers and learners and distance learning has already been part of many higher learning institutions programmes now. Durak and Ataizi (2020) reported that based on a study conducted, almost all learners felt that distance learning platforms offer great convenience in terms of time and location. Despite advancement of digital technologies, it is important to note that learners vary in their abilities to understand learning materials. There will be situation that some learners are able to understand and follow and analyse data immediately while others are not able to do so. There are still learners who lack such ability despite many learners being able to utilise the technological tools and are a bit slow at learning new online platforms. These are the a few either learners who required special assistance from their teachers or classmates who are technology-based skilled (Blackstone et al., 2007).

The use of WMPs (web-mobile platforms), Telegram application for example supports teaching and learning enhancement by providing a quick way and easy platform for sharing information among teacher and learners (Ibrahim et al., 2016). By using Telegram, people are able to create groups for up to 5000 people for broadcasting to infinite audiences (Vivienne, 2016). Furthermore, in a study focusing on transparent and ubiquitous learning (Mokhtar, Hussin \& Embi, 2015), selected Edmodo platform for interactive lectures due to its interesting simple features which includes simple ways in file sharing and online communicating, encourage a peer-learning and a peer-support environment both in classroom and online as well with various website layout templates and a secured environment. Therefore, the scenario given above prompted this study to look into the potential of WMPs, Edmodo and Telegram to benefit learners and educators by providing solutions to the main challenges of time and space constraints learners faced while engaging in English language learning acquisition via the WMPs thus resolve the problems that contributes to the learners' language learning process.

Learning continuum is the stage whereby learners will keep on learning while engaging in a language classroom until certain prescribed objectives are met and achieved by the students as part of their lifelong learning journey; when learning is pursued throughout life, flexible, diverse and available at different times and different places (Delors, 1996).

\section{Literature Review}

Language learning may take place in the virtual learning environment platform when learners utilize the language learning materials provided and interact with each other via online. Language acquisition occurs subconsciously by means of exchanging information, ideas or experiences with each other. While learners become aware of their mistakes and begin to self-correct the mistakes, they are learning consciously as claimed by Krashen's Second Language Theory or SLA (2009) or known Krashen 1982 Monitor Theory. 
In relation to this study, the language learning materials in Edmodo and interactions in Telegram will act as the scaffolding to assist ODLs while participating in language learning. Edmodo and Telegram act as the scaffolding of the Zone of Proximal Development (ZPD) that facilitate learners' language learning-acquisition process. According to Vygotsky (1978), ZPD is the distance between the actual development level determined by learners' independent ability to solve problems and the level of potential development determined by learners' ability to solve problems with guidance from the teachers or from more competent individuals or peers. Vygotsky further elaborates that when appropriate support or some sort of assistance (scaffolding) are provided to the learners to perform a certain task through social interactions, thus motivate learners to accomplish the given task because learners are within the ZPD that consists of Actual Development Zone and Potential Development Zone. Hussin (2008) stated that the more learners make use of the scaffolding utilities to learn-acquire the knowledge and skills, the bigger their Potential Development Zone will become. Once learners are able to master a certain task, gradually the scaffolding will then be removed (Galloway, 2001).

The use of WMP, Edmodo, allows teachers and learners to share content and educational applications, access assignments and tasks given, know their grades, conduct class discussions in a secured manner. The findings from a research conducted by Abd. Moen and Hussin (2015), found that Edmodo benefited teachers and learners in the acquisition of vocabulary in ESL (English Second Language) classrooms. Furthermore, no additional costs were required to subscribe to Edmodo since it is free, and can be used by both teachers and learners, which makes it easier to be exploited by anyone at any time convenient to them. Edmodo is a secured learning platform designed by Jeff O'Hara and Nick Borg back in 2008 for teachers, students and parents to be able to participate in an online community (Kongchan, 2013). Even though the emergence of various social media sites, software and other aids available to assist language learning, Edmodo has been identified as the future platform of English language learning through interviews conducted by Mokhtar and Dzakiria, (2015).

In the meantime, Telegram, another form of WMP is becoming popular among both academicians and the general population as well. Telegram in education and training, are relatively innovative concept that has been the central concern of many academicians, teachers and parents in the education community. Moreover, Telegram can provide opportunities for educators to easily display research studies results. Baran (2013) stated that university students have embraced the capabilities of social media channels and based on the statistics, a major part of students' energy and time is devoted to reading formal and informal online texts on various social media channels either synchronous or asynchronously and following updates related to the course content. Telegram offers great opportunities for learners to acquire language. The immense popularity of social networking websites such as Telegram has created new opportunities for English learners nowadays to learn the language.

\section{Problem Statement}

Garland (1994) identified some situational challenges for the ODLs to be persistence in distance learning which include poor learning environment and lack of time. Meanwhile in tertiary scenario in Malaysian context, Hussin (2004) outlined problems encountered by ODLs while studying into four distinct factors, which are time management, family matters, career development and motivation. In addition, time management has been the most common problem the ODLs have to deal with (Hussin, 2004). Thus, sufficient amount of learning interactions and learning support is vital among ODLs because they will endeavor in a new 
learning environment and the expectations that the ODLs would have independent learning skills and the capacity to engage themselves in activities that require self-direction and managing their own learning, as stated by McLoughlin and Marshall (2000).

According to Belanger and Jordan (2004), distance learning is a type of education and training delivered to individuals who are geographically dispersed or separated by physical distance from the instructor, using computer and telecommunication facilities. Distance learning allows adult learners who have employment, family or other responsibilities to update knowledge and skills related to their job by saving travel costs and allowing a flexible schedule, as mentioned by Park \& Choi (2009). However, in this study, throughout their study at the university, ODLs are only exposed to the formal learning of the language to 4 contact hours per semester for a range of 4 meetings in a semester. Exposure in terms of credits and the amount of hours allocated for the learning of the English language is very minimal especially for the open distance learners at tertiary level.

Therefore, there is a need to provide more opportunities to ODLs to be engaged in language learning environment as they only meet their lecturers once a month in a semester. The ODLs will only take part in language practices when they meet face-to-face interaction in class; and on the other hand, when the class is concluded, there will be no assurance that ODLs will practice the language outside the classroom. Lack of learning time, interactions between learners and teachers, learners and learners among themselves will be the challenges, which ODLs would face when they enroll themselves as ODLs in a virtual learning environment. Hence, this study looks into how the WMPs; Edmodo and Telegram may assist ODLs in resolving their learning time and space constraints while engaging in the English language learning-acquisition.

The outcome of this study would be able to provide some new insights to how the learning of English language can be complemented by the use of the WMPs among the ODLs and significant in enhancing language learning through the WMPs in Malaysian higher learning institutions.

\section{Methodology}

Purposively sampling was employed involving eleven undergraduate Malaysian ESL ODLs to conduct the current study. They were from a local university situated in Johor. In terms of technological skills, all the learners were computer-literate, possess sufficient knowledge and skills to be able to use the computers and were familiar with the operation of computers along with necessary abilities to access the internet using smart phones or other gadgets as well. All the ODLs have basic computing and internet skills because these are the skills required in their work place.

The instrumentations used in this study were a questionnaire and in-depth interview questions on the use of both WMPs; Edmodo and Telegram to elicit responses from the learners. The findings are presented in a narrative manner to illustrate the emerging themes and the pedagogical implications pertaining to how the WMPs provided learners opportunities to learning resources beyond the classroom learning time and space constraints

\section{Findings}

\section{Questionnaire and Interview Questions}

The questionnaire and the interview questions were designed to further investigate the use of Edmodo as a teaching-learning platform and Telegram as a mobile-based environment in language learning. The questionnaire and the interview questions consist of 
a series of questions with regards to the learners' learning time and space constraints. The questions look into learners' opinions and views on learning independently, learners' ideas regarding the limitation of learning time and space constraints during the learning process while getting involved in the language learning acquisition via the web-mobile platforms. As for the interview questions, four learners were randomly selected.

The questionnaire and interview questions were distributed to eleven learners at the end of the semester (Meeting 4; final meeting) to acquire the learners' feedback and opinions on using the platform as a language-learning platform and gathered information about their opinions, feelings and points while taking part in the virtual learning platforms. The learners were only exposed to the formal face-to-face learning time of 4 contact hours per semester for a range of 4 meetings in a semester. The researcher provided the learners with the required and sufficient information regarding the questions on the usage of Edmodo and Telegram as the web-mobile platforms. The researcher also consulted the learners to seek further information and explanation if the questions might remain unclear to them. The learners were also asked to write their answers completely and explain their responses clearly. They were given ample time to respond to the questions.

\section{Findings for the questionnaire on Telegram}

The researcher used the data obtained from the questionnaire to answer the underlying statement on time and space constraints. The presentation of data analysis starts with the questionnaire on Telegram apps while Edmodo platform was conducted by using the interview questions. Therefore, it is significant to point out that questions (Q1-Q6) in the questionnaire is categorised into two main themes as follows; frequency of online participation and self-learning which focused on the learning time and space constraints learners faced while using the web-mobile platforms in the language learning-acquisition. Meanwhile the interview questions (Q1-Q5) looked into learners' views on learning language using the Edmodo platform from the perspective of time and space constraints.

\section{Frequency of online participation}

The result on frequency of going online (Q1-Q3) showed that all the 11 learners stated that they would go online anytime during their free time. Next, 7 learners admitted they would respond to their classmates' postings immediately. 6 learners described themselves as moderate learners in terms of online interaction in the Telegram platform while 3 learners said that they were active.

\section{Self-learning}

8 learners out of 11 agreed that self-learning (Q4-Q6) which took place outside the classroom via Telegram was as an alternative solution for the learning process and said that it was good and helpful for them. Three learners added that;

R2: "English-language learning group will allow you to lean on each other for support and ask questions to others who are in the process of learning English".

R5: "It is a new experience for students".

R9: "Help me to improve my English".

Meanwhile on the topic of time learners' spent for answering questions in Telegram and in the classroom, 6 of the learners mentioned that they would immediately respond to questions in Telegram as compared to in the classroom because they were excited and happy while 2 learners stated that; 
R3: $\quad$ "It depends. Some things actually prefer discussion in class and sometimes it easier to just answering in Telegram".

R5: "I took more time to answer questions in telegram because I'm not always holding my phone. While in classroom I can only focus to answer the questions."

Having information and knowledge as well as additional materials beyond the class lessons in Telegram was helpful and useful according to the 9 learners. In addition, two learners mentioned that;

R3: "good because it can further enhance the understanding of learning that is learned".

R5: "I can get a lot more of information not just in class but in telegram with the sharing tips and materials by others that can improve the lessons".

As a conclusion, with regards to time and space constraints, based on the learners' feedback, they would usually go online anytime whenever they were not occupied with other commitments and during their free time. They also responded to the thread in Telegram as soon as possible. The learners agreed that self-learning outside the classroom was an alternative solution to learn independently and Telegram apps provided them opportunities of self-managed learning via the learning platform. Having additional information and learning materials in Telegram were helpful and useful for the learners in language learningacquisition process.

\section{Findings for the Interview Questions on Edmodo}

The interview questions (Q1-Q5) looked into learners' views on learning language using the Edmodo platform from the perspective of time and space constraints. The results indicated that learners interviewed agreed that Edmodo platform helped them learned English language anytime and anywhere possible regardless of time and space constraints. Even though learners were away from the classroom in terms of mobility and communication, they could still participate online in the discussion forum that would also helped learners to communicate with their classmates and lecturer easily.

Apart from that, based on the feedback, it can be concluded that Edmodo platform provided the learners opportunities to interact among each other outside the classroom even though they were not able to attend class especially when it comes to revision for test period time. Learners mentioned that Edmodo allowed the lecturer to post assignment and upload learning materials via online and learners could download the materials easily. Learners could also participate when having discussion online in Edmodo platform based on the postings whenever they were unable to attend class, they could still attempt the exercises given subsequently.

Responding to the question on how fast the lecturers would respond to their questions posted online, learners mentioned that lecturer would respond promptly as stated by them;

R1: $\quad$ "Lecturers correct any mistakes in the questions as students post them and respond positively to correct questions, and there remains a record of this. students can look back and see where their mistakes were and what the correct version is".

R2: "Yes, I believe they respond as early as possible".

R3: $\quad$ "It depend on the question. But most of the time, lecturer is much helpful and fast reply in answering all the questions".

R4: "Yes, lecturer will brief a little bit for questions given before class start". 
It can be concluded that in terms of time and space constraints, the use of Edmodo platform helped learners to resolve their learning time and space constraints due to the fact that learners were not bound to any specific time or space constraints while engaging themselves online via Edmodo platform as compared to normal classroom situation.

\section{Discussions}

In this vast world nowadays, every person would attempt to stay connected with each other by using different technologies and gadgets or devices to be able to exchange information and ideas. When asked about the issue of time constraint required for participating in the web-mobile learning platforms, it indicated that the learners were satisfied as there was no time limitation for them to share and post their ideas and opinions with their fellow classmates outside the classroom at anywhere and anytime possible. Participating actively in the web-mobile platforms will help learners to improve their information seeking skills on English language anywhere and anytime possible beyond the normal classroom situation. The learners have the opportunity to study and learn not only in a normal classroom situation but also outside the classroom whenever and wherever they want. By doing this, learners will be able to self-managed their own learning pace and improved skills. Song et. al (2004) emphasised that time management was another important factor in assisting learners during online learning. In order to be an active participant in the online learning process, learners are required to manage their own self-learning. Learners were given the privilege to make use of the language-learning guides provided in the webmobile platforms and learn independently. Therefore, learners must take full charge and responsibility for their outcomes (Gurleen \& Deepak 2010).

Distance learning required an impressive range of technologies to enable teachers and ODLs to communicate with each other and be able to access education and learning opportunities at certain time and place to cater individual learning preferences (Dzakiria and Christopher, 2010). Ilgaz and Gülbahar (2015) added that the most important dimension related to learners' readiness is access to available technology. In addition, interactions with the teachers and the frequency of involvement to the online interactions with technical and administrative support are contributing factors that made distance online learning successful. It is important to note that teachers teaching ODLs are required to undertake some changes to be engaged in new ways of teaching and understand what are the things involved in distance learning and be accountable in their reassessment of teaching. Distance learning is not merely introducing and using new technologies of communication but to be able to understand the process of teaching and learning. On the contrary, in this current study, all the learners who took part in the web-mobile platforms activities faced no difficulties in accessing and making use of the language learning materials and the online discussion as well. This is whereby the web-mobile platforms may help learners to complement classroom teaching and learning situation and as for the learners, they could overcome their weaknesses in different language skills by using the language-learning guides and supports via the webmobile platforms.

The learners shared their ideas and opinions with their course mates in an interactive online discussion in the WMPs. They were able to gain more information and knowledge from their fellow classmates through the online discussions. The learners made use of their friends' comments and suggestions. It is advisable for the learners to make use of the learning platform or any other online language learning tools available in order to become active learners and learn independently. The web-mobile platforms in addition showed that the 
learners participated in the discussion forums and shared postings related to the tasks, opinions and thoughts at any time they felt convenient for them to participate in the learning environment.

The use of web-platforms indicated that the learners were not bound to the time limitation in order to participate in English learning-acquisition activities because they were able to take part at any time convenient to them to be involved in the online discussions or share thoughts and opinions. Having no learning time and space limitations allowed learners to make use of the language learning materials in the platform and enhance their independent learning. Learners made use of the scaffolding elements aspects to help them engaged in an online learning experience by using the learning platforms, Edomodo and Telegram.

To conclude, the study suggests the practicality and convenient ways of engaging in language learning-acquisition using the WMPs thus bridge physical spaces and time constraints between learners and educators.

\section{Acknowledgements}

I would like to thank Prof. Dr. Supyan Hussin, UKM, for having the opportunities to collaborate with him in preparing this article. The quotations, summaries and sources have been properly and duly acknowledged.

\section{References}

Abd. Moen, N., \& Hussin, S. (2015). Edmodo in Action: EnhancingVocabulary Acquisition among Second Language Learners. In Proceedings of the International Language and Education Conference: Language \& Education Prospect and Competitiveness in the Era of Globalisation (iLEC2013-82) [CD]. Negeri Sembilan: Universiti Sains Islam Malaysia

Al-Hunaiyyan, A., Alhajri, R. A., \& Al-Sharhan, S. (2018). Perceptions and challenges of mobile learning in Kuwait. Journal of King Saud University - Computer and Information Sciences. 30(2). 279-289

Al-Rahmi, W. M., Othman, M. S., \& Yusuf, L. M. (2015). The effectiveness of using e-learning in Malaysian higher education: A Case Study Universiti Teknologi Malaysia. Mediterranean Journal of Social Sciences, 6(5S2), 625-637

Baran, E. (2013). Connect, participate and learn: Transforming pedagogies in higher education. Bulletin of the IEEE Technical Committee on Learning Technology, 15(1), 912

Begley, C. M. (1996). Triangulation of communication skills in qualitative research instruments. Journal of advanced nursing. 24(4), 688-693

Belanger, F., \& Jordan, D. H. (2004). Evaluation and Implementation of Distance Learning: Technologies, Tools and Techniques. Turkish Online Journal of Distance Education 5(2), 99-101

Bicen, H. (2015). The role of social learning networks in mobile assisted language learning: Edmodo as a case study. Journal of Universal Computer Science. 21(10), 1297-1306

Blackstone, B., Spiri, J., \& Naganuma, N. (2007). Blogs in English language teaching and learning: Pedagogical uses and student responses. Reflections on English Language teaching. 6(2), 1-20

Bush, G. (2006). Learning about learning: from theories to trends. Teacher Librarian, 34(2), 14-19

Delors, J. (1996). Learning: The treasure within. Paris: UNESCO Publishing 
Detel, W. (2015). Social Constructivism. In International Encyclopedia of the Social \& Behavioral Sciences: Second Edition. 228-234

Driscoll, M. (2005). Psychology of Learning for Instruction, (3rd ed.). Boston, MA: Pearson Education Inc

Durak, G., \& Ataizi, M. (2020). Learner Views about a Distance Education Course. Contemporary Educational Technology, 7(1)

Dzakiria, H., \& Christopher, A. (2010). Interaction issues in Malaysia open distance learning (ODL).Retrieved from: http://oasis.col.org/bitstream/handle/11599/2131/2010_Dzakiria\%26Christopher_Int eraction_issues_ODL.pdf?sequence=1\&isAllowed=y

Etikan, I. (2016). Comparison of Convenience Sampling and Purposive Sampling. American Journal of Theoretical and Applied Statistics, 5(1)

Galloway, C. (2001). Vygotsky's constructionism. Retrieved from: http://www.it.studio.coe.uga.edu/ebook/

Garland, M. R. (1994). The adult need for " personal control" provides a cogent guiding concept for distance education. Journal of Distance Education, 9(1), 45-59

Greenhow, C., \& Lewin, C. (2016). Social media and education: reconceptualizing the boundaries of formal and informal learning. Learning, Media and Technology, 41(1), 630

Gurleen, A., \& Deepak, A. (2010). Language learning with internet-based projects: A studentcentred approach for engineering students. ESP World, 9(1), 1-12

Hung, M. L., \& Chou, C. (2015). Students' perceptions of instructors' roles in blended and online learning environments: A comparative study. Computers and Education, 81, 315325

Hussin, S. (2004). Hidden voices of adult learners in open and distance learning program: Problems and strategies to overcome the problems. In First COLLA Regional Workshop, Putrajaya, Malaysia, 28-29

Hussin, S. (2006). Revisiting online forum in language teaching. Plenary paper presented at ASIACALL, 26-28 Nov 2006. UPM

Hussin, S. (2008). Creating A Bigger Z.P.D. For ESL Learners Via Online Forum in Malaysia. The College Teaching Methods and Styles Journal, 4(11),1-10

Ibrahim, N.M., Norsaal, E., Abdullah, M.H., Che Soh, Z.H., \& Othman, A. (2016). Teaching and Learning Enhancement Based on Telegram Social Media Tool. Journal Intelek, 11(1), 711

Ilgaz, H., \& Gülbahar, Y. (2015). A snapshot of online learners: e-Readiness, e-Satisfaction and expectations. International Review of Research in Open and Distributed Learning, 16(2), 171-187

Kongchan, C. (2013). How Edmodo and Google Docs can change traditional classrooms. The European Conference on Language Learning 2013. Retrieved from: https://docplayer.net/10565983-How-edmodo-and-google-docs-can-changetraditional-classrooms-chada-kongchan-king-mongkut-s-university-of-technologythonburi-thailand.html

Krashen, S. D. (2009). Principles and Practice in Second Language Acquisition. NY: Pergamon. Retrieved from: http://www.sdkrashen.com/content/books/principles_and_practice.pdf

McIntyre, G. A. (2005). A Method for Unbiased Selective Sampling, Using Ranked Sets. The American Statistician. American Statistical Association, 59, $230-232$ 
McLoughlin, C., \& Marshall, L. (2000). Scaffolding: A model for learner support in an online teaching environment. Retrieved from: www.c3l.unioldenburg.de/cde/support/readings/loughlin2.htm

Mokhtar, F. A. (2018). Breaking barriers through Edmodo: A qualitative approach on the perceptions of University of Malaya undergraduates. Online Learning Journal, 22(1), 61-80

Mokhtar, F. A., \& Dzakiria, H. (2015). Illuminating the Potential of Edmodo as an Interactive Virtual Learning Platform for English Language Learning and Teaching. Malaysian Journal of Distance Education, 17(1), 83-98

Mokhtar, M., Hussin, S., \& Embi, M. A. (2015). Edmodo for Interactive Lecture: a focus on transparent and ubiquitous learning In M. Amin Embi (Ed.) e-Learning and interactive Lecture: SoTL Case Studies in Malaysian HEls. Bangi: Pusat Pengajaran dan Teknologi Pembelajaran UKM, 183-194

Naderi, S., \& Akrami, A. (2018). EFL learners' reading comprehension development through MALL: Telegram groups in focus. International Journal of Instruction, 11(2), 339-350

Norman, H., Nordin, N., Din, R., Ally, M., \& Dogan, H. (2015). Exploring the roles of social participation in mobile social media learning: A social network analysis. International Review of Research in Open and Distance Learning, 16(4), 205-224

Orey, D. C., \& Rosa, M. (2015). Three approaches in the research field of ethnomodeling: emic (local), etic (global), and dialogical (glocal). Revista Latinoamericana de Etnomatemática, 8(2)

Park, J., \& Choi, H. J. (2009). Factors Influencing Adult Learners Decision to Drop Out or Persist in Online Learning. Educational Technology \& Society, 12, 207-217

Song, L., Singleton, E. S., Hill, J. R., \& Koh, M. H. (2004). Improving online learning: Student perceptions of useful and challenging characteristics. The Internet and Higher Education, 7(1), 59-70

Thirusanku, J., \& Yunus, M. M. (2014). Status of English in Malaysia. Asian Social Science, 10(14), 254-260

Vivienne, W. (2016). With Telegram, A Reclusive Social Media Star Rises Again. Retrieved from: http://fortune.com/telegram-pavel-durov-mobile-world-congress/

Vygotsky, L. S. (1978). Mind in Society. Cambridge, Massachusetts: Harvard University Press

What is Distance Learning? (2020). Retrieved from:

https://www.viewsonic.com/library/education/what-is-distance-learning-and-why-isit-so-important/

Yanti, H., \& Setiawan, A. (2018). Teacher's Perception about the use of E-Learning/Edmodo in Educational Activities. In IOP Conference Series: Materials Science and Engineering. 306 (1). 012055. IOP Publishing

Yunkul, E., \& Cankaya, S. (2017). Students' attitudes towards Edmodo, a social learning network: A scale development study. Turkish Online Journal of Distance Education, 18(2), 16-29 


\section{Appendix}

\section{Telegram Questionnaire}

1. When do you usually go online? Weekends/free time.

2. If your classmates post something in Telegram, would you respond to the posting? How fast?

3. How do you describe yourself in the interaction in Telegram? Active/Moderate/Passive? Why?

4. What is your opinion about self-learning outside the classroom via Telegram?

5. What is your opinion about the time you spent for answering questions in Telegram and in the classroom?

6. What is your opinion on having information and knowledge as well as extra/additional materials beyond the class lessons in Telegram?

\section{Edmodo Interview Questions}

1. How does Edmodo help you improve your English?

2. Do the materials uploaded in Edmodo benefit you in learning English? How?

3. Do the comments and responses provided by your lecturer helped you improve your proficiency and understanding of the assignments? How? In what way?

4. Does Edmodo help improve spelling and grammar when posting in complete words and sentences? Comment.

5. Do you think you can improve listening skills through the audio files uploaded in Edmodo? How? 